\title{
Maryblyt v. 7.1 for Windows: An Improved Fire Blight Forecasting Program for Apples and Pears
}

William W. Turechek, U.S. Department of Agriculture, Agricultural Research Service, Ft. Pierce, FL 34945; and Alan R. Biggs, West Virginia University, Kearneysville Tree Fruit Research and Education Center, P.O. Box 609, Kearneysville 25430

Accepted 22 December 2014. Published 27 January 2015.

\section{ABSTRACT}

Turechek, W. W., and Biggs, A. R. 2015. Maryblyt v. 7.1 for Windows: An improved fire blight forecasting program for apples and pears. Plant Health Progress doi:10.1094/PHP-RS-14-0046.

This article describes updates found in Version 7.1 of the fire blight prediction model Maryblyt, originally developed by Paul Steiner and Gary Lightner. In addition, a brief history of the development of the Maryblyt model is given. The article ends with examples comparing the

\section{INTRODUCTION}

Fire blight is caused by the bacterium Erwinia amylovora (Burr.). It is one of the most destructive diseases of apple and pear worldwide. The symptoms of fire blight were first described over 200 years ago in the Hudson Valley of New York (Denning 1794; van der Zwet and Keil 1976), but the causal agent E. amylovora was not identified until a century later (Burrill 1883; van der Zwet and Keil 1976). There are five distinct phases associated with fire blight, not all of which occur every year or with equal intensity. These are the blossom, canker, shoot, root, and trauma blight phases. However, it is the blossom blight phase of the disease that warrants the greatest attention because it offers growers the opportunity to break the disease cycle and limit the potential destructiveness of the shoot, root, and trauma blight phases.

Historically, management of blossom blight has been difficult because this phase is sporadic geographically and temporally, and its severity is dependent on a number of interacting factors with weather conditions, disease history, and cultivar susceptibility being the most influential. When agricultural streptomycin first became available, growers adopted intensive management practices that relied heavily on its application at frequent, regular intervals because of the destructive and sporadic nature of the disease. This approach, although generally adequate, seldom afforded complete control, sometimes failed, and was often excessive given the amount of disease that subsequently developed in comparable non-treated orchards. Such control strategies were not only costly and wasteful, but also afforded the pathogen an environment for potential resistance development.

Today, blossom blight is managed with far greater success and with fewer streptomycin applications using disease forecasters such as Maryblyt ${ }^{\mathrm{TM}}$. Maryblyt predicts fire blight infection events by identifying periods when weather conditions and tree

Corresponding author: W. W. Turechek. Email: William.Turechek@ars.usda.gov doi:10.1094/PHP-RS-14-0046 C 2015 The American Phytopathological Society performance of Version 7.1 to Version 4.3c, the last version that was validated and released prior to its upgrade to Maryblyt 7.0 for Windows. We show that Version 7.1 provides results nearly identical to the previously validated DOS version 4.X. phenology are suitable for infection, allowing growers to time antibiotic applications when they can be most effective. The purpose of this article is to describe the updates found in Maryblyt version 7.1. But first, an abbreviated history of Maryblyt is given. Unfortunately, there are informational gaps in the development timeline that are not easily filled, as there is limited documentation on how Maryblyt evolved over the years, particularly in the earlier years. Moreover, no instruction manuals were prepared for versions 1 and 2 so tracking the evolution and/or changes in some of the key parameters proved to be difficult. Nonetheless, this article should paint the most complete history of the development of one of the most widely used and successful forecasters of plant disease used today.

\section{RESEARCH AND DEVELOPMENT}

Dr. Paul Steiner (1942-2000), professor of botany at the University of Maryland, was the creator of the fire blight forecasting system that was eventually named Maryblyt. Dr. Steiner began searching for a better method to predict infection of apple by E. amylovora in the late 1970s. By 1983, he had established a collaborative group with several other plant pathologists in the eastern United States to develop an effective warning system for managing fire blight (van der Zwet et al. 1987). This group consisted of Joseph G. Barrat, West Virginia University; Kenneth D. Hickey, Penn State University; Keith S. Yoder, Virginia Tech University; and Tom van der Zwet, USDA. Although pears are the commercial crop most susceptible to $E$. amylovora, apple was selected as the crop for model development because the high susceptibility of pears to the pathogen has limited (and continues to limit) the development of a substantial pear industry in the eastern United States. The initial focus was to determine the conditions necessary for blossom infection. This approach was taken for several reasons. First, the open blossoms provide a large number of vulnerable infection points and therefore represent a critical risk point in the growing season. Blossom infections can be controlled with properly timed streptomycin applications, thus an accurate blossom infection model would be a useful and effective tool. Finally, the necrosis 
from a blossom infection is easily visible, allowing the model to be easily validated.

In 1986, Dr. Steiner began his collaboration with Gary Lightner, a computer programmer at the USDA-ARS Appalachian Fruit Research Station in Kearneysville, WV, and initiated a discussion of the requirements for creating a computer model. At this time, only the degree-hour calculations used for the estimation of bacteria population established by Zoller and Sisevich (1979) were actually put into use. From 1984 to 1986 , the collaborators collected weather and fire blight data from the four states involved (i.e., Maryland, Pennsylvania, Virginia, and West Virginia), with Steiner collecting additional data from other locations, including Indiana, Maine, Massachusetts, Michigan, and Ohio. The cooperative effort seemed to validate the $65^{\circ} \mathrm{F}$ $\left(18.3^{\circ} \mathrm{C}\right)$ average temperature threshold established by Mills (1955) and the degree hour accumulation described by Zoller and Sisevich (1979). To these requirements, Steiner would add additional criteria: (1) that the blossoms must be open and intact; and (2) a wetting event, such as dew or rainfall or a rainfall greater than 0.1 inch $(0.25 \mathrm{~mm})$ the previous day, is required for infection to occur.

Independently, through careful analysis of well-documented blossom infection events, Steiner further developed a degree-day model for symptom development. He found that after an infection occurred, the symptoms would begin to appear 90 degree-days $>55^{\circ} \mathrm{F}\left(50 \mathrm{DD}>12.7^{\circ} \mathrm{C}\right)$ later. This allowed for examination of control effectiveness. The grower would now know when to inspect the orchard for blossom infection and was provided a tool to manage control strategies. If an unexpected infection appeared in the orchard, the conditions 90 degree-days $>55^{\circ} \mathrm{F}$ (50 $\mathrm{DD}>12.7^{\circ} \mathrm{C}$ ) previous to that point could be scrutinized to determine the cause of the infection event. In 1987 Steiner and Heflebower published two abstracts dealing with prediction of fire blight infections of apple in Maryland. One dealt with blossom infections (Steiner and Heflebower 1987a), the other with over wintering canker activity (Steiner and Heflebower 1987b).

\section{THE EARLY VERSIONS}

In March 1988, Steiner presented Lightner with a six-page document entitled "Suggested Rules for the Mary Blite Apple Fire Blight Predictive Model" and work on a comprehensive fire blight prediction program began (see Steiner and Heflebower 1987c). This document not only included parameters for blossom infection, but for canker, shoot, and trauma blight events as well. Also included were copies of Steiner's data sheets and hand drawn charts. From the outset, Steiner was adamant that the program not require expensive equipment to obtain the necessary inputs, only a min-max thermometer and a rain gauge. The daily inputs were date, phenological stage, minimum temperature, maximum temperature, and the amount of rainfall. These inputs remain today as the program inputs, however rainfall is now referred to as a wetting event. With this information, the Maryblyt model calculated average daily temperature, degree-days greater than $55^{\circ} \mathrm{F}\left(12.7^{\circ} \mathrm{C}\right)$ (for keeping track of symptom development), and daily degree-hours greater than $65^{\circ} \mathrm{F}\left(18.3^{\circ} \mathrm{C}\right)$ (to track the bacterial population). Both degree-days and degree-hours were also kept as accumulated values. Degree-days were calculated using the average of the minimum and maximum daily temperatures and began at green tip. Degree-hours were calculated using six hours at the minimum daily temperature, six hours at the maximum daily temperature, and twelve hours at the average daily temperature and began at first bloom. The coldweather rules were also established early on. In response to freezing temperatures, accumulated degree-hours were to be reduced to 0 if the daily temperature dropped below $32^{\circ} \mathrm{F}\left(0^{\circ} \mathrm{C}\right)$. In response to cool temperature (lasting one or more days), accumulated degree-hours were reduced by a third if the maximum daily temperature was below $65^{\circ} \mathrm{F}\left(18.3^{\circ} \mathrm{C}\right)$, a second consecutive day with the maximum below $65^{\circ} \mathrm{F}\left(18.3^{\circ} \mathrm{C}\right)$ would require the value to be cut in half, and a third consecutive day with a maximum below $65^{\circ} \mathrm{F}\left(18.3^{\circ} \mathrm{C}\right)$ would set the accumulated degree-hours to 0 .

In this first version, the conditions (parameters) necessary for each of the blight events as well as subsequent symptom development were defined as follows (note: these are not the current parameters).

Blossom Blight. A blossom infection would be triggered if all four of the following events occurred: (1) blossoms were open with stigmas exposed and petals intact; (2) the daily average temperature was equal to or greater than $65^{\circ} \mathrm{F}\left(18.3^{\circ} \mathrm{C}\right)$; (3) 198 degree-hours $>65^{\circ} \mathrm{F}\left(110 \mathrm{DH}>18.3^{\circ} \mathrm{C}\right)$ were accumulated from first bloom) or 130 degree-days $>55^{\circ} \mathrm{F}\left(72 \mathrm{DD}>12.7^{\circ} \mathrm{C}\right)$ were accumulated from green tip; and (4) a heavy, wetting dew or a rain $\geq 0.01$ inch $(0.25 \mathrm{~mm})$ or a rain of $\geq 0.10$ inch $(2.5 \mathrm{~mm})$ occurred the prior day. Symptoms of a blossom blight infection event would become visible with the accumulation of 90 degreedays $>55^{\circ} \mathrm{F}\left(50 \mathrm{DD}>12.7^{\circ} \mathrm{C}\right)$ from the date of infection. At this time the $+/-$ system to identify the four risk categories was implemented. If blossoms are not present, the infection risk is NONE. Open blossoms create a LOW risk if no other condition is positive. The risk is MODERATE with open blossoms and if one of the other conditions is met, HIGH with open blossoms and with two of the other conditions, and an INFECTION occurs if all four conditions are met. These values indicate the relative risk of infection, not expected disease severity.

Canker Blight. Overwintering canker activity was defined to indicate when cankers become active. This activity was shown to occur after the accumulation of 130 degree-days $>55^{\circ} \mathrm{F}$ (72 $\mathrm{DD}>12.7^{\circ} \mathrm{C}$ ). Shoot and limb symptoms associated with canker blight were expected to become visible with the accumulation of 220 degree-days $>55^{\circ} \mathrm{F}\left(122 \mathrm{DD}>12.7^{\circ} \mathrm{C}\right)$ from green tip. To observe/verify activity, the bark was removed at the edge of the canker margin. If the margin between the healthy and necrotic tissue is sharp and clear the canker is inactive. If the margin becomes diffuse or brown streaks are clearly protruding from the margin, the canker is active.

Shoot Blight. At this time, shoot blight was only noted as developing following the transmission of the pathogen from systemically invaded tissues to healthy shoots by insects. Specifically, winged adults of the white apple leafhopper (Typhlocyba pomaria McAtee) and aphids were noted as possibilities.

Trauma Blight. A trauma infection can be initiated with either hail damage or if the temperature dropped below $28^{\circ} \mathrm{F}\left(-2.2^{\circ} \mathrm{C}\right)$ and can expected any time after early bloom with the accumulation of 110 degree-hours $>65^{\circ} \mathrm{F}\left(61 \mathrm{DH}>18.3^{\circ} \mathrm{C}\right)$. If a trauma event occurs, symptoms can be expected after the accumulation of 130 degree-days $>55^{\circ} \mathrm{F}\left(72 \mathrm{DD}>12.7^{\circ} \mathrm{C}\right)$ after the event.

With conditions now fully defined, the program name was changed to Maryblyt and it appeared for the first time in a 1988 abstract in the journal Phytopathology (Steiner 1988). Throughout that year, however, modifications were made to the program and the changes were evaluated using data collected in previous years and with new data as it became available. Early in 1989 a new set of parameters were outlined and, for a brief period, the name Fireblyt was considered although it only appeared in 
correspondences with collaborators. The epiphytic inoculum potential rules were modified so that after an accumulation of 300 degree-hours $>65^{\circ} \mathrm{F}\left(167 \mathrm{DH}>18.3^{\circ} \mathrm{C}\right)$ no reduction is made if temperatures dropped below $32^{\circ} \mathrm{F}\left(0^{\circ} \mathrm{C}\right)$. Conditions for shoot blight were also defined. Either blossom or canker symptoms must be present and a rain, which would infect young shoots below the initial infection point, or suitable insect vectors be present to disperse the bacteria and create damage, and therefore, a point for infection. Shoot blight symptoms were expected to occur 90 degree-days $>55^{\circ} \mathrm{F}\left(50 \mathrm{DD}>12.7^{\circ} \mathrm{C}\right)$. Insect vectors discussed were the white apple leafhopper, green apple aphid (Aphis pomi DeGeer), and rosy apple aphid (Dysaphis plantaginea Passerini). The white apple leafhopper required the least amount of accumulated heat units to mature, approximately 650 degree-days $>40^{\circ} \mathrm{F}\left(361 \mathrm{DD}>4.4^{\circ} \mathrm{C}\right)$, and was used as the threshold for insect vector presence. High winds and general foliage, shoot, or fruit damage were added as trauma initiating events.

In June 1989, Steiner and Lightner attended the Fifth International Workshop on Fire Blight held in Diepenbeek, Belgium. Four papers were presented at this meeting on the topic of Maryblyt covering (1) prediction of apple blossom infections (Steiner 1990a), (2) prediction of canker, shoot, and trauma blight (Steiner 1990b), (3) description of the computer model version 2.0 (Lightner and Steiner 1990), and (4) comparison between Maryblyt and the Billings system (van der Zwet et al. 1990). As reported, growers using this early version of Maryblyt were able to reduce the traditional three sprays to two, one, or none at all and symptoms usually were predicted to within a day. By this time, cooperators supplied data from Illinois, Massachusetts, Missouri, New Hampshire, New York, Ohio, Utah, Virginia, Washington, and West Virginia in the United States, as well as from Ontario, Canada, and prototypes of the model had been tested for two years.

The creation of a computer program to execute the model provided users an easy way to enter, modify, and display the data. Tedious calculations were eliminated and errors reduced. Data could be toggled between metric and English units and be printed, displayed in chart form or graphically. The user could modify certain model thresholds to enhance the model's accuracy. The program allowed the grower to track up to ten blossom and trauma infection events simultaneously. One of the most important additions to the model was the ability to enter forecasted weather data to provide the user with a display of potential future conditions based on the supplied information. This was named "Prediction Mode" and it allowed the grower to more effectively plan and prepare for spray applications and to observe rapid changes in infection potential that can occur with fire blight.

\section{LATER VERSIONS}

Several researchers independently validated Maryblyt versions 3 and 4 within the first few years of its introduction (Jones 1992; van der Zwet et al. 1994, respectively). Given Maryblyt's success, Version 4.0 of the software was commercialized in 1992 and, along with the newly prepared Maryblyt manual, was distributed by Gempler's Inc. (Janesville, WI). Additional improvements to the algorithm were introduced in Versions 4.2, 4.3a, 4.3b, and $4.3 \mathrm{c}$, including the use of a mathematical sine wave functionrather than averaging the daily maximum and minimum temperatures - to calculate degree day and degree hour determinations to reduce the prediction errors that were experienced in more arid regions of the country, and a degreehour-based blossom life calculator for both apple and pear (the final DOS product was version 4.3c). Incorporation of the sine wave function also meant changing the standard infection-toearly-symptom interval from 90 to 103 degree-days $>55^{\circ} \mathrm{F}(57$ $\mathrm{DD}>12.7^{\circ} \mathrm{C}$ ). In spite of these programming improvements, Maryblyt remained a DOS-based program during a time when the Microsoft Windows 95 and 98 operating systems were quickly becoming well established. Many Maryblyt users had difficulty running the program under the DOS shell that came with the Windows software. The DOS-based Maryblyt rapidly became obsolete as it became increasingly problematic for casual computer users to run DOS-based programs in a Windows environment. Moreover, the cost to obtain the program remained sufficiently high $(\sim 250)$ to deter all but a few commercial apple and pear growers, crop consultants, and some university faculty from obtaining the program.

The first Windows' version of Maryblyt became available in 2003 with Version 5, which was not widely distributed. Lightner translated the source code from its original Pascal coding to $\mathrm{C}+$. The work was supported with funding from the USDA's Northeast IPM research grants program to the authors of this article. Also with Version 5, Gempler's released the program from its commercial license and the program was made freely available. The program, however, remains copyrighted and use of the Maryblyt name is protected and may only be used with permission of the Steiner estate.

Version 5 was less than optimal on the Windows platform because of coding deficiencies and was quickly revised to the short-lived Version 6 and then, in 2009, to Version 7. The source code for Version 7 was translated from $\mathrm{C}+$ to $\mathrm{C \#}$. The reprogramming was done by Biggs and Turechek (2010) under a subcontract to Eric Sonchaiwanich in 2009. In this version, rudimentary Excel-style spreadsheet functionality was built-in to Maryblyt allowing users to cut and paste data to and from Excel, to export data files in comma-delimited format, and a new graphics module was developed. Also, Version 7 was programmed so that all model parameters, not just the main thresholds, could be adjusted to allow users to highly customize the program. The only algorithmic change to occur in Version 7 was that the 80 degree day clock would reset to 0 if the minimum daily temperature $\leq 24^{\circ} \mathrm{F}\left(-4.4^{\circ} \mathrm{C}\right)$. This is because $90 \%$ of the blossoms will be killed if exposed to temperatures $\leq 24^{\circ} \mathrm{F}\left(-4.4^{\circ} \mathrm{C}\right)$ for $1 \mathrm{~h}$. An overview of fire blight and Maryblyt 7.0 can be found in Biggs and Turechek (2010).

\section{MARYBLYT 7.1}

Maryblyt 7.1 was released in 2014 . Version 7.1 incorporates several cosmetic and functional changes; the re-programming for Version 7.1 was done by Turechek and Biggs under a subcontract to Walter Britton. Among the changes, Version 7.1 is capable of using international units for decimal numbers (e.g., 20,3) and date formats (DD/MM/YYYY) and this is initiated by selecting the "International" option through the Season Properties dialogue box (Fig. 1). Earlier versions were able to accept only U.S. units for numbers and dates, and the program would invariably "crash" if the wrong number and/or date formats were used. The audible warning beep, which was missing in Version 7.0, was reestablished to alert users of an infection event. The additional option allowing users to toggle the beep on and off was also incorporated into Version 7.1 (Fig. 1). The Maryblyt manual was also revised, reformatted, and integrated into the program software as a PDF file.

Another option that has been added to Maryblyt 7.1 is the ability to turn on and off the effect that applying an antibiotic has on EIP and subsequent blossom blight symptoms (BBS)(Fig. 2). 
This is particularly useful so that users can track symptom development as if they had not treated with antibiotics so that BBS can be monitored more effectively and application effectiveness can be evaluated. In a typical scenario, once a spray has been applied, the infection event (denoted as "I" under the BHWTR) will usually be downgraded to a high risk event ("H") because the EIP is often reduced to below 198 due to the antibiotic application. As a result, the BBS clock will not be activated. However, because applications are less than perfect, it is likely that some infection may have occurred and it is of interest to initiate the BBS clock to track infection. To accomplish this, users can turn off the Spray Mode (Fig. 2), temporarily removing the application to allow users to identify when blossom blight symptoms would be expected as if an application was not made.

A new feature in Maryblyt 7.1 is the Spray Effectiveness Module which allows users to enter an application efficacy threshold to account for treatments that are less than $100 \%$ effective. This can be accessed under the Program Thresholds dialogue box (Fig. 3). In earlier versions of Maryblyt it was assumed that when an antibiotic was applied, coverage was thorough, that all flowers open at the time of treatment were protected, and that the chemical treatment (generally agricultural streptomycin) was $100 \%$ effective. However, in practice these assumptions often are not met. Users can now account for less than perfect applications (i.e., we often advise growers that streptomycin applied the day after infection is only $90 \%$ as effective as streptomycin applied the day before or day of

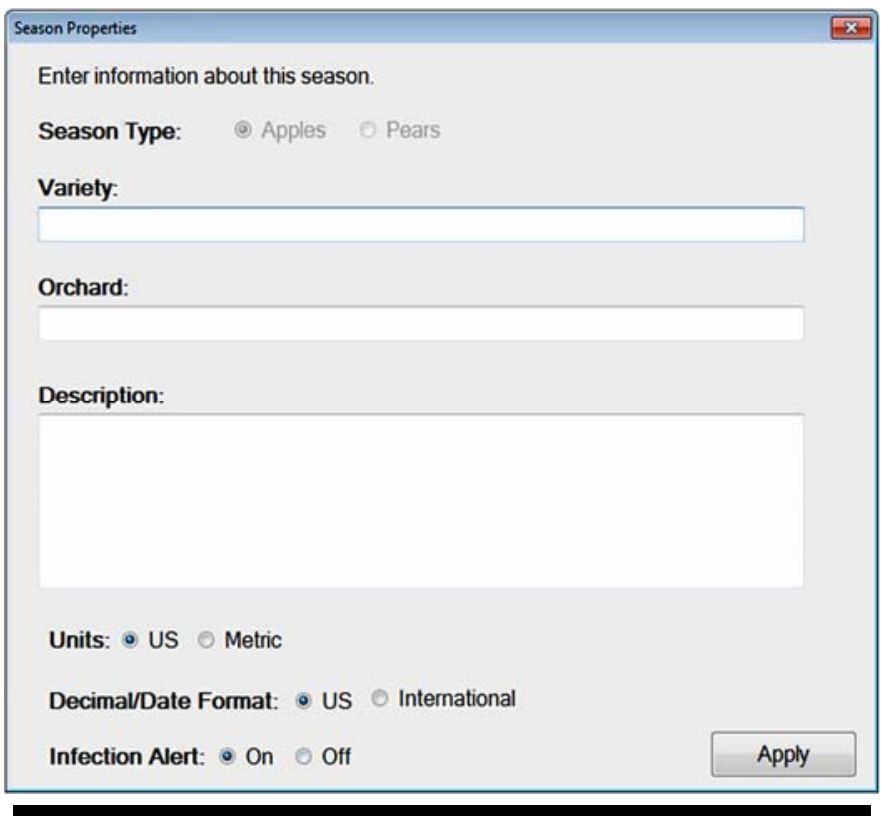

\section{FIGURE 1}

The Season Properties dialogue box provides options for choosing measurement units, decimal and date formats, and whether the infection alert beep is on/off.

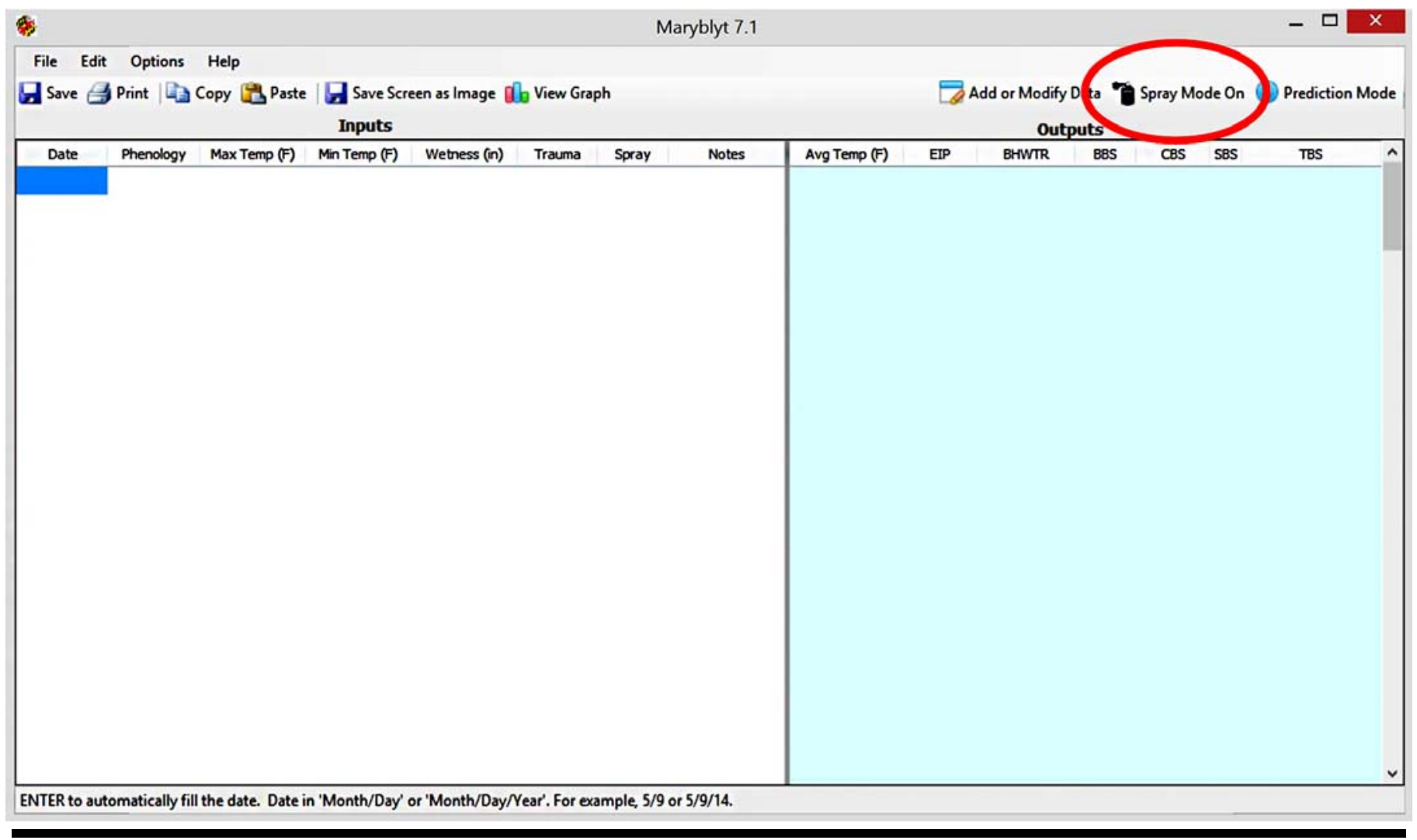

\section{FIGURE 2}

The Spray Mode button located on the main spreadsheet (circled in red) provides users the ability to temporarily remove (= "off") antibiotic applications entered under the spray column. This allows users to track symptom development (BBS) as if an antibiotic had not been applied. The motivation for this option is to account for less than perfect applications so to alert growers when to scout for disease. When the Spray Mode is "on" the effects of the antibiotic application are returned. 
infection), or for applications of alternatives to streptomycin that are known to be less effective, by entering an estimate of the actual level of efficacy into the Spray Effectiveness box. When this is done, the accumulated number of degree-hours is reduced by a factor equal to (100 - \% Spray Effectiveness) and subsequent EIP calculations are reset to begin from the date of application; i.e., the 65 degree hour clock starts on the date of application. Users should be aware and are warned that this feature is conceptual and has not been tested or validated.

\section{EXAMPLES OF MARYBLYT 7.1}

The output of Maryblyt 7.1 was compared to that of Version $4.3 \mathrm{c}$, the last version of Maryblyt coded in Pascal for DOS and released by Steiner. Three examples of the output are shown in Table 1 . Here, we used data that were provided in the appendix of the manual for Maryblyt 4.3 and are from the bloom periods labeled Demo 1, Demo 3, and Demo 4 in the manual, but shown here as examples 1, 2, and 3, respectively. Example 1 is a season that summons the rules for a 3-day cold event (4/23-25). Example 2 begins with the bloom period experiencing several cold days and nights with temperatures below freezing; no degree-hours are accumulated. In fact, on 4/24, a small number of degree-hours would have been accumulated had the minimum temperature not dipped below freezing. Example 3 is an example of a severe blossom blight season. The differences between Version 4.3 and Version 7.1 outputs are shown in boldface in Table 1 . Only slight differences were seen in examples 2 and 3 and these were the result of differences in the rounding protocol. In version 4.x of Maryblyt, the degree days were rounded to the nearest integer before being converted to degree hours (i.e., $\mathrm{DH}=24 * \mathrm{DD})$ ). In the current version, the degree days are not rounded before calculating degree hours, and this would sometimes make difference in the calculation. Despite these differences in the degree day/hour calculations, there were no differences in the risk ratings in these particular examples.

Table 2 shows results obtained from adjusting the spray efficacy setting using a portion of the data from example 3 in Table 1. In this example, the number of degree-days greater than $40^{\circ} \mathrm{F}$ (DD40), the number of degree-hours $>65^{\circ} \mathrm{F}$ (DH65), and the cumulative number of degree-hours $>65^{\circ} \mathrm{F}(\mathrm{CH} 65)$ accumulated over the 80 degree day blossom window are shown. The starting date for the 80 degree-day window, i.e., where to begin tallying degree-hours, is shown under the column labeled "Win." An application with $100 \%$ and $90 \%$ efficacy was applied on $4 / 25$. In both cases, the 80 degree-day window resets to start on $4 / 25$ and 216 fewer degree-hours $(456-312)$ are added to the 144 degreehours accumulated on $4 / 26$, the day after the spray was applied,

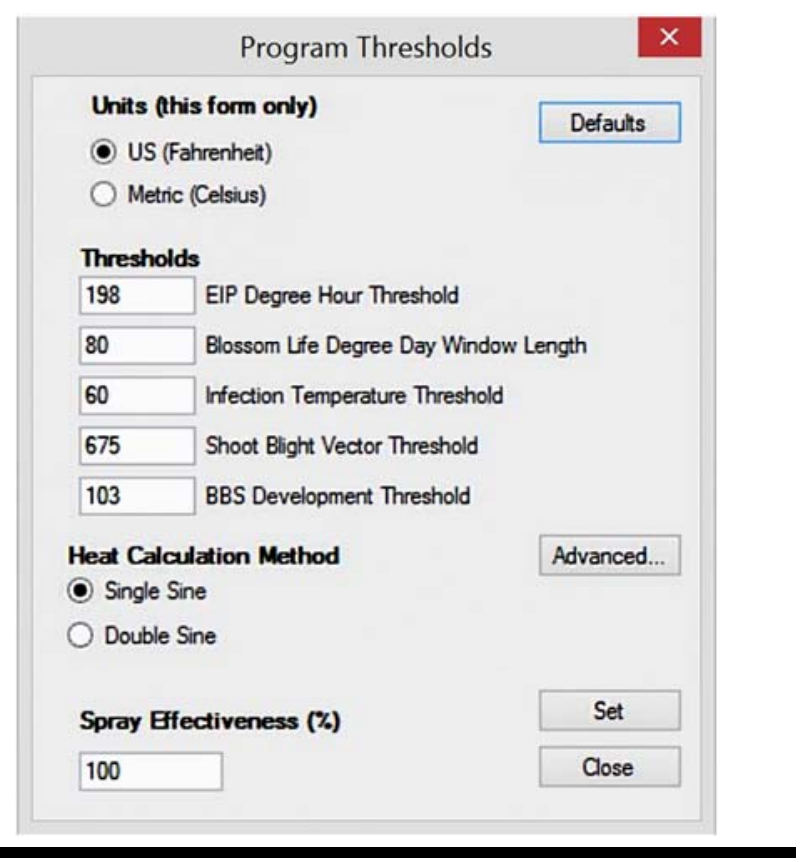

FIGURE 3

The Program Thresholds dialogue box, in addition to accessing all program thresholds, has the added option of setting the spray efficacy; a new feature in version 7.1. This parameter reduces the accumulated number of degree-hours by a factor equal to (100 $\%$ Spray Effectiveness) and subsequent epiphytic inoculum potential calculations are reset to begin from the date of application.

relative to the untreated example. With $100 \%$ efficacy the total degree-hours accumulated on 4/26 would simply be 144 , the number accumulated on that day. With $90 \%$ efficacy, there is a residual of 46 degree-hours $(456 \times 10 \%)$ on $4 / 25$ (the day of the application) that is added to the 144 accumulated on $4 / 26$. With $90 \%$ efficacy, the EIP exceed 100 two days earlier than the example with $100 \%$ efficacy.

\section{OBTAINING THE SOFTWARE}

Maryblyt version 7.1 can be downloaded from the West Virginia University Kearneysville Tree Fruit Research and Education Center web site at: http://www.caf.wvu.edu/kearneysville/Maryblyt. Questions regarding the use of the model can be directed to the authors. 


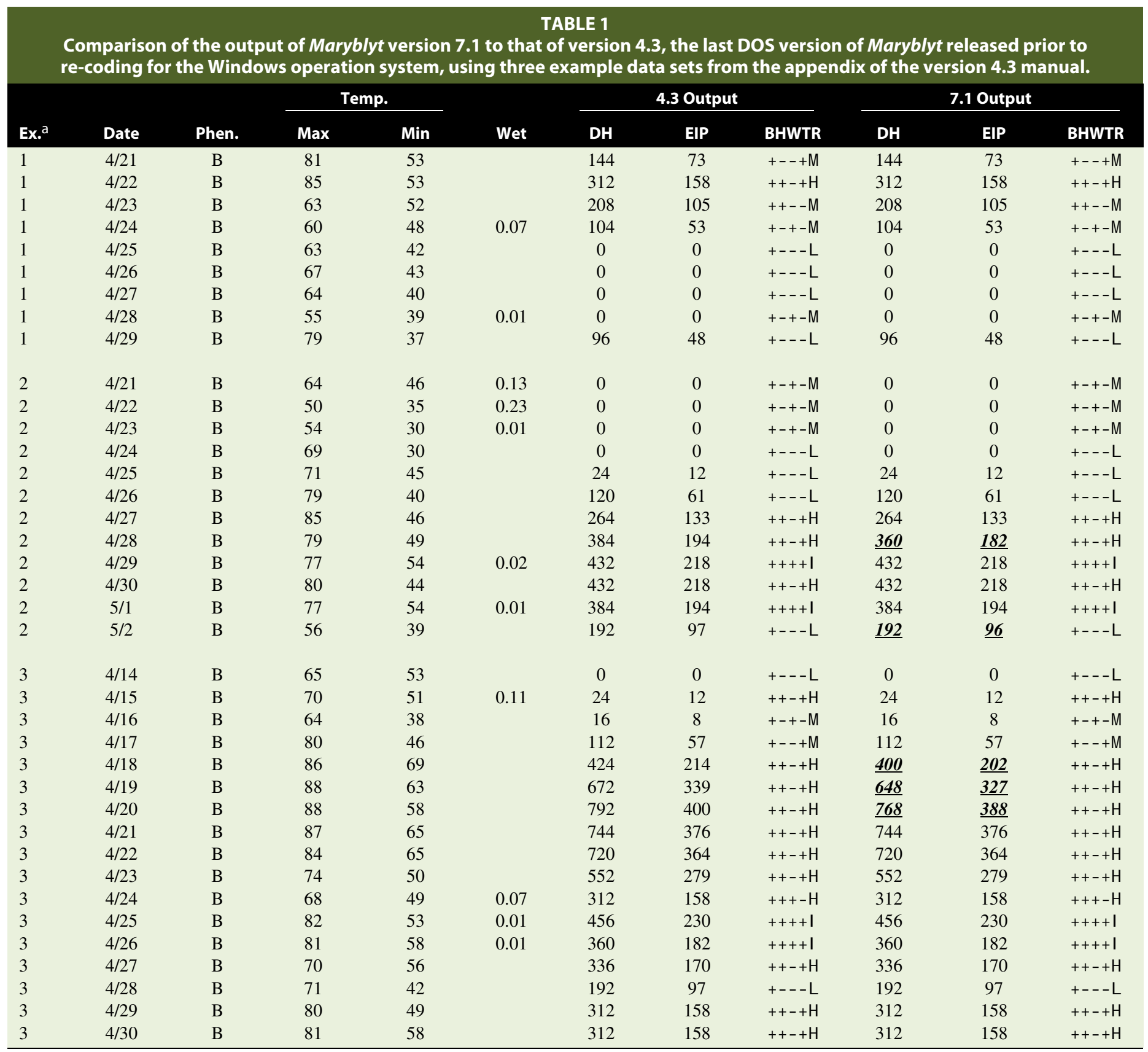

${ }^{\mathrm{a}}$ Ex. $=$ Example, Phen. $=$ phenology $(\mathrm{B}=$ bloom period $)$, Wet $=$ wetting period (given in inches of precipitation $), \mathrm{DH}=\mathrm{degree}-\mathrm{hours}, \mathrm{EIP}=$ epiphytic inoculum potential (when EIP $\geq 100$, the bacterial population has reached or exceeded the threshold for infection), BHWTR = risk rating (this is a binary rating (+/-) to indicate if blossoms (B) are open and whether the EIP (H), Wetness (W), or Temperature (T) thresholds have been met. The risk rating $(\mathrm{R})$ of low $(\mathrm{L})$, medium $(\mathrm{M})$, high $(\mathrm{H})$ or infection $(\mathrm{I})$ is indicated when 1, 2, 3, or 4 of the requirements have been met, respectively. 


\begin{tabular}{|c|c|c|c|c|c|c|c|c|c|c|c|c|c|c|c|}
\hline \multirow[b]{3}{*}{ Date } & \multirow{2}{*}{\multicolumn{10}{|c|}{$\begin{array}{l}\text { TABLE } 2 \\
\text { setting using a sul } \\
\text { Spray = } 100 \%\end{array}$}} & \multirow{2}{*}{\multicolumn{5}{|c|}{ Spray $=90 \%$}} \\
\hline & & & & & & & & & & & & & & & \\
\hline & Win $^{a}$ & DD40 & DH65 & CH65 & EIP & Win & DD40 & DH65 & CH65 & EIP & Win & DD40 & DH65 & CH65 & EIP \\
\hline $4 / 21$ & $4 / 19$ & 36 & 264 & 744 & 376 & $4 / 19$ & 36 & 264 & 744 & 376 & $4 / 19$ & 36 & 264 & 744 & 376 \\
\hline $4 / 22$ & $4 / 20$ & 34 & 240 & 720 & 364 & $4 / 20$ & 34 & 240 & 720 & 364 & $4 / 20$ & 34 & 240 & 720 & 364 \\
\hline $4 / 23$ & $4 / 21$ & 22 & 48 & 552 & 279 & $4 / 21$ & 22 & 48 & 552 & 279 & $4 / 21$ & 22 & 48 & 552 & 279 \\
\hline $4 / 24$ & $4 / 22$ & 18 & 24 & 312 & 158 & $4 / 22$ & 18 & 24 & 312 & 158 & $4 / 22$ & 18 & 24 & 312 & 158 \\
\hline $4 / 25$ & & 28 & 144 & 456 & 230 & & 0 & 0 & 0 & 0 & & 0 & 14 & 46 & 23 \\
\hline $4 / 26$ & $4 / 23$ & 30 & 144 & 360 & 182 & $4 / 25$ & 30 & 144 & 144 & 73 & $4 / 25$ & 30 & 144 & 190 & 96 \\
\hline $4 / 27$ & $4 / 24$ & 23 & 24 & 336 & 170 & & 23 & 24 & 168 & 85 & & 23 & 24 & 214 & 108 \\
\hline $4 / 28$ & $4 / 26$ & 16 & 24 & 192 & 97 & & 16 & 24 & 192 & 97 & & 16 & 24 & 238 & 120 \\
\hline $4 / 29$ & & 24 & 120 & 312 & 158 & & 24 & 120 & 312 & 158 & & 24 & 120 & 358 & 181 \\
\hline $4 / 30$ & $4 / 27$ & 30 & 144 & 312 & 158 & $4 / 27$ & 30 & 144 & 312 & 158 & $4 / 27$ & 30 & 144 & 312 & 158 \\
\hline
\end{tabular}

a Win $=$ The starting date for the 80 degree-day window, DD40 $=$ The number of degree-days greater than $40^{\circ} \mathrm{F}$, DH65 = The number of degreehours $>65^{\circ} \mathrm{F}, \mathrm{CH} 65=$ The cumulative number of degree-hours $>65^{\circ} \mathrm{F}$ accumulated over the 80 degree day blossom window, and EIP $=$ epiphytic inoculum potential (when EIP $\geq 100$, the bacterial population has reached or exceeded the threshold for infection).

\section{LITERATURE CITED}

Biggs, A. R., and Turechek, W. W. 2010. Fire blight of apples and pears: Epidemiological concepts comprising the Maryblyt forecasting program. Plant Health Progress doi:10.1094/PHP-2010-0315-01-RS.

Burrill, T. J. 1883. New species of Micrococcus (bacteria). Amer. Nat. 17:319. Denning, W. 1794. On the decay of apple trees. N.Y. Society for the Promotion of Agricultural Arts and Manufacturers 2:219-222.

Jones, A. L. 1992. Evaluation of the computer model Maryblyt for predicting fire blight blossom infection on apple in Michigan. Plant Dis. 76:344-347.

Lightner, G., and Steiner, P. W. 1990. Computerization of a blossom blight prediction model. Acta Hort. 273:159-162.

Mills, W. D. 1955. Fire blight development on apple in western New York. Plant Dis. Rep. 55:206-207.

Steiner, P. W. 1988. Maryblyt: A predictive model for eastern apple fire blight. Phytopathology 78:1571.

Steiner, P. W. 1990a. Predicting apple blossom infections by Erwinia amylovora using the Maryblyt model. Acta Hort. 273:139-148.

Steiner, P. W. 1990b. Predicting canker, shoot and trauma blight phases of apple fire blight epidemics using the Maryblyt program. Acta Hort. 273:149-158.

Steiner, P. W., and Heflebower, R. 1987a. Prediction of apple fire blight blossom infections in Maryland, 1984 to 1986. Phytopathology 77:989.
Steiner, P. W., and Heflebower, R. 1987b. Prediction of apple fire blight overwintering canker activity in Maryland, 1984 to 1986. Phytopathology 77:989-990.

Steiner, P. W., and Heflebower, R. 1987c. Mary Blite: A predictive model for apple fire blight management. Proc. Cumberland-Shenandoah Fruit Workers Conf., Nov. 19-20, 1987.

Thomson, S. V. 1986. The role of the stigma in fire blight infections. Phytopathology 76:476-482.

van der Zwet, T., and Keil, H. L. 1979. Fire Blight - A Bacterial Disease of Rosaceous Plants. USDA Handbook 510, Washington, DC.

van der Zwet, T., Lightner, G., Walter, J., and Steiner, P. W. 1990. Comparison of the Maryblyt predictive model with the Billing Revised System for blossom blight risk assessment in apple. Acta Hort. 273:171-184.

van der Zwet, T., Biggs, A. R., Heflebower, R., and Lightner, G. W. 1994. Evaluation of the MARYBLYT computer model for predicting blossom blight on apple in West Virginia and Maryland. Plant Disease 78:225-230.

van der Zwet, T., Steiner, P. W., Barrat, J. G., Hickey, K. D., and Yoder, K. S. 1987. Development of a blossom blight prediction system for the Appalachian fruit growing region. Acta Hortic. 217:125-132.

Zoller, B. G., and Sisevich, J. 1979. Blossom populations of Erwinia amylovora in pear orchards vs accumulated degree-hours over $18.3 \mathrm{C}$ (65F), 1972-1976. Phytopathology 69:1050 